Marquette University

e-Publications@Marquette

$1-1-2002$

\title{
The "Income-Variance" Risk Factor and Jones \&" Laughlin v. Pfeifer Guidelines for the Calculation of Present Value
}

Charles Breeden

Marquette University, charles.breeden@marquette.edu

Published version. Journal of Forensic Economics, Vol. 15, No. 1 (2002): 19-29. DOI. (C) 2002 National Association of Forensic Economics (NAFE). Used with permission. 


\title{
The "Income-Variance" Risk Factor and Jones \& Laughlin v. Pfeifer Guidelines for the Calculation of Present Value
}

\author{
Charles H. Breeden*
}

\section{Introduction}

Papers that discuss the appropriate discount rate to be used on calculating the present value of future losses are so numerous that writing such papers could be characterized as a cottage industry. For a smattering of contributions, see for example, Havrilesky(1988), Peláez (1989 and 1997), Albrecht and Moorhouse (1989), Nowak, (1991), Bell and Taub (1990 and 1999), Haydon and Webb (1992), Bonham and La Croix (1991), Haslag, Nieswiadomy, and Slottje, (1994) and Ewing, Payne, and Piette (2001). Related articles discuss projected earnings growth rates and the "net" discount rate that is the residual of offsetting an earnings growth rate against a discount rate. There is also the issue of "real" or inflation-free discount rates versus "nominal" discount rates.

A recent exchange in the literature directs our attention to the variance and not just the level, of inflation forecasts and implications for the consideration of risk. This exchange suggests a consideration of the variance of income itself over the course of a typical worklife and the question arises: Has the existence of potential year-to-year variance in projected earnings of an injured victim been sufficiently understood and accounted for in our calculations of present value? Believing the answer to this question to be in the negative, this paper attempts to state and clarify issues regarding this "income-variance" risk factor.

The proximate cause of the comments ventured here was an exchange in the Fall 1999 number of the Litigation Economics Digest between Professors Bell and Taub (comment) on the one hand, and Professor Ireland (response) on the other hand. The issues revolved around "risk adjustments" in damage calculations of present value. Ireland (1997) had argued that since inflation risk involves both upside and downside exposure (unanticipated variance in actual inflation over forecast period), then unanticipated variance in actual inflation over the time period of the forecast merely increases the variance, not the mean, of future returns and hence does not require any adjustment to the discount rate. Ireland further argued that a default premium for termination of the income stream needn't be considered in present value calculations because such calculations already contain an adjustment for survival and workforce attachment probabilities. To additionally burden expected future earnings would involve double counting. Bell and Taub take issue with both of these

\footnotetext{
*Associate Professor, Economics Department, Marquette University, Milwaukee, WI. An earlier version was presented at SEA/NAFE meetings in Washington, D.C., November 12, 2000
} 
contentions in their short comment by citing a principle of finance that only future cash flow streams that are "certain" are entitled to discounting at a "risk-free" rate. Stated in the opposite manner, non-certain returns require at least some form of adjustment for risk, a risk "premium." Ireland replies that case law (especially Jones \& Laughlin v. Pfeifer) requires risk-free discount rates and that any uncertainty regarding the income stream should be reflected in the projected level or length of income.

Before turning to a fuller discussion of respective arguments, it is worth pointing out the essential agreement in approach of the two sides. Both parties acknowledge that in matters of present value calculation, "the real problem... is one of accounting for all factors that might limit a future earning stream" (Ireland, 1999, p.157). Thus there is no disagreement that the present value of future earnings should reflect the potentials for reduced earnings flow due to death or incapacity. There is also a mutual understanding that riskiness associated with the earning stream should be accounted for in some fashion although the precise method (by reductions to the earning assumption itself or by considering a higher non risk-free discount rate) is itself debatable.

\section{The Main Argument}

The idea raised in Bell and Taub's comment that concerns us here is that in the typical present value calculation, "no adjustment is made to recognize the uncertainty of future productivity growth." Any variance in such a growth rate over the life of the lost income would constitute $a$ form of uncertainty and would thus potentially provide a basis for reduction in present value via a higher, non-risk free discount rate. This general perspective is not novel with Bell and Taub. Earlier, Margulis (1992) had argued essentially the same point with respect to the level of the income stream rather than the growth rate of income. He had argued for "parity in risk," a finance term, in the valuation of future loss streams. Margulis maintained that the only proper arena in which to utilize a risk-free discount rate is in the projection of a risk-free and constant earning stream. All earnings projections that involve some uncertainty over the year-to-year earning level or growth rate are to be valued at a nonrisk free discount rate. It is noteworthy that Margulis' numerous references did not include an article from any Economics and Law journal nor did they include a reference to Journal of Forensic Economics. His foundation sources were from finance and his central notion of the requirement of "risk parity" is a principle of finance. Later, Biederman and Baesemann (1996), responding to a comment by Albrecht (1992), echoed Margulis' point and attempted to show that if compensatory damages are the goal, then principles of financial economics compel us to employ non-risk free discount rates except for the unlikely cases where individuals are indifferent to risk. Like Margulis, they ultimately ground their argument in the finance literature.

\section{Principles of Finance and Forensic Economists' Calculations}

Thus a principle of finance (that only "certain" future payment streams are to be valued at the risk-free discount rate) is cited and utilized by Margulis, 
Biederman and Baesemann, and Bell and Taub to comment on the proper discount rate. If it is proper to apply the finance principle to the calculation of present value of lost earning streams, then current practice of discounting earning streams by risk-free government bond or bill rates becomes suspect. For a given expected value (e.g. median or most likely earnings) forecast, discounting at the US Treasury Bond rate would imply that the earnings were a "certain" stream (absent any other adjustment). Discounting uncertain future earnings at a non-risk free corporate bond rate would seem to account for the possibility of uncertainty of payments as that rate reflects a premium for the possibility of default.

In their discussions of "factors that limit a future earning stream" (Ireland p.157) and "factoring in the problem of non-survival and non-participation" (Bell and Taub p.154), both sides are clearly responding to the same ultimate goal of a fair and accurate measurement of damages. Ireland states "it seems logical to account for all risks to the earning stream itself or to account for all risks with premia in the discount rate" (p.158).

In Ireland's mind, Bell and Taub conflate risk adjustment strategies. If the calculation has explicitly reduced earnings for death and workforce attachment probabilities, then uncertainty over earnings has been accounted for and imposing a risk premium on the discount rate would "double-burden" income projections. Further, Ireland feels that Pfeifer and case law demand the use of risk-free discount rates, thus present value calculations must necessarily use LPE adjustments to earning streams to factor in all other relevant kinds of risk. This is the central question between Ireland and Bell and Taub.

\section{Proper Risk Adjustment: To Earning Stream or to Discount Rate?}

Ireland's presumption that risk-free rates are required by case law leads directly to his conclusion that all other risks must be folded into adjustments to the earning stream. "The important point is that Pfeifer sets a standard that is applied in many legal venues, both state and federal, regardless of the "rightness" or "wrongness" of the Pfeifer court's opinion regarding discount rates." (Ireland, p.157) Yet the Pfeifer standard of "risk-free" discount rates closes the door on a consideration of any type of uncertainty in income stream not translatable into an adjustment to the length or level of the income stream. Clearly this allows consideration of the chief uncertainties confronted by forensic economists related to income projection, namely their expected length, and their expected level. LPE adjustments in fact allow uncertainty related to the length of worklife to be collapsed into calculations of the level of earnings.

The important point here is that if uncertainty exists related to the constancy of projected income growth rates through time, or uncertainty over the level of income year-to-year, then another dimension of risk is present and may need to be accounted for in some way. The variance can be either period-to-period changes in income or in a variance in the growth rate over the forecast period, whatever its mean value. The risk of income variance is separate from the risk of income cessation, although it would be fair to interpret temporary income cessation as an extreme form of variance. While there may be alternate ways to account for it in a present value calculation and while its inclusion 
may or may not be warranted on other grounds, it seems clear that an income stream that fluctuates about a mean level or mean growth rate is less desirable than the income stream with a constant level or growth rate. The complex set of characteristics that distinguishes small company from large company incomes no doubt includes the observed greater unpredictability of small company returns year-to-year. Thus the extra return required by investors to hold small company stocks reflects their perception of risk. Risk can thus in this context be defined as uncertainty about the course of future events that would translate into an observed differential in return of the sort that divides average returns from large company returns from small company.

With Ireland and many others relying on the language of the Pfeifer decision for direction on matters of present value calculations, the decision deserves a further examination. If the principle of finance is correctly applied to forensic economists' present value economic calculations, then it remains to be established that the legal framework within which forensic economists operate allows the finance principle into evidence. Although the direction of US Supreme Court opinion in science matters after the trilogy of Daubert, Joiner, and Kumho Tire is clearly toward having the "best science" represented in courtrooms, existing rules of evidence still apply.

The Pfeifer Decision

The decision in Pfeifer touches on several key elements of the forensic economist's calculation of present value of income streams.

1. Inflation

2. Taxes

3. Growth rate assumption

4. Discount rate assumption

5. Length of loss period

6. The type of investment for the awarded lump sum

\section{Inflation}

In paragraph (d) on page 524 (as a referee pointed out, differing reporting systems use different page numbers creating a challenge for the reader following a different reporting service version), the court makes clear its understanding of the need for consistency in the handling of inflation in the earnings forecast and the discount rate forecast. "As long as inflation continues, the amount of the 'offset' against the market rate should be chosen on the basis of the same factors that are used to estimate the lost stream of future earnings." (continued to page 525) The court demonstrates an understanding of the difference between real and nominal interest rates. "The relevant real interest rate is the difference between the short term market interest rate in a given year and the average rate of price inflation during that same year." (page 543, in footnote 26 continuing from page 542.)

\section{Taxes}

The court also referenced Liepelt regarding the use of after-tax income. The federal jurisdiction required that losses be computed on an after-tax basis. 
Loss Period

In this case, the court abided by the use of age 65 as this was agreed to by the two parties.

\section{Growth Rate}

On page 536, the Court refers to productivity increases as "a permanent feature of the national economy" and makes clear that such increases will increase workers' wages and should be considered in calculating the proper award.

\section{Discount Rates}

On page 537, the Court gives its fullest discussion of discount rates. Referring to and quoting liberally from the standard citation, Chesapeake \& Ohio Railway Company v. Kelley, the Court writes "the ascertained future benefits ought to be discounted in the making up of the award" (Chesapeake, p.490). They go on to state "The discount rate should be based on the rate of interest that would be earned on "the best and safest investments" (Chesapeake, p. 490). They conclude that (their words, not Chesapeake) the injured worker "is entitled to a risk-free stream of future income to replace his lost wages; therefore the discount rate should not reflect the market's premium for investors who are willing to accept some risk of default" (Pfeifer, p. 537).

It is noteworthy that here they explicitly mention the risk of default, the permanent cessation of income, and not the risk of variance in income from period to period (higher than average some years and lower others). The cessation of income including the probability of any premature cessation due to death can be, and routinely is, factored into the present value calculation by an LPE adjustment. If we distinguish between the cessation of income and the irregular nature of income that does not experience cessation, we can see that the court in Pfeifer did not directly address the "variance of income" dimension that arises in the exchange between Bell and Taub and Ireland. This is the basis for my conclusion that Pfeifer "sees" neither the issue of income variance nor the implications for discount rates, and it cannot be taken as the definitive legal ruling on an issue that it does not specifically address. In addition, if indeed the Pfeifer Court failed to see the issues with the eyes of modern finance and economic theory, must it remain so for eternity? Is not the overarching desire of the Supreme Court, as revealed in Daubert and elsewhere, that sound principles of modern science hold sway in courts of law? Is it not the responsibility of forensic economists to put forth their best notions of what is correct, and let the rules of evidence be settled by jurists and legal writers? Is this an instance of "path dependence [as] an important phenomenon in law" (Posner, 2001 p. 157)? If so, then perhaps we should follow Judge Posner in interpreting "law... as a servant of [the] social need" (p. 159) of precision in damage measurement. 


\section{Type of investment}

The Court identifies that the discount rate should reflect a rate of interest "that would be earned on "the best and safest investment" (referring again at page 537 to Chesapeake, page 491.) At page 541, it is noted that Canada uses $7 \%$ return to long-term investments minus an inflation forecast. It is also noted that Australia uses a (presumably risk-free) " $2 \%$ real market rate." The Court's terminology of "best" and "safest," while sensible on the surface, upon reflection is subject to multiple interpretations. Interpreting "best" in terms of safety renders the phrase completely redundant. Yet other interpretations see "best" as an investment that is within the management capabilities of the average injury victim or reflective of the victim's ideal risk/return profile. Interpreting "best" to mean the highest yielding investment renders the phrase contradictory because higher (than risk-free) yields can only be achieved by the assumption of some risk.

On page 548, after rejecting price inflation forecasts and reciting the famous quote about "not converting trial courts into graduate economics seminars," the Court goes on to say "it is necessary to choose an appropriate belowmarket rate of interest" (my emphasis.) They go on to state that trial courts using between $1 \%$ and $3 \%$ would rarely be reversed. After this, three paragraphs below, they state that, after accounting for inflation and societal factors affecting wage increases, "then these wage growth factors should be set off against the market interest rate in an estimation of future price inflation" ( $p$. 548.)

From the snapshot view of Pfeifer, it becomes apparent that the Supreme Court used the case to address several specifics relating to the forensic economists' present value calculation. It is also apparent that while displaying much understanding, the Court also displays some confusion and leaves a number of important issues subject to varied interpretation. While at times giving the instructions cited by Ireland regarding risk-free discount rates, the Court also creates confusion by referring to both "market" and "below-market" interest rates, by displaying both the "return on investment" and the "reduced future earning stream" interpretations, and by considering the cessation of income streams but not their possible variance. Thus Pfeifer supports Ireland's interpretation and at the same time provides ample leeway for alternative interpretations as well.

\section{A Hypothetical Illustration}

\section{An Example of Two Earning Streams}

Consider an illustrative hypothetical case involving twin brothers of equal, innate productivity characteristics, identical training with degrees in accounting from the same institution with identical grade point averages. They undertake similar job searches but brother B chooses to go to work in the Bursar's office at the college from which they graduated and brother A decides to become a free-lance financial advisor specializing in athletes in professional sports. Let us further assume that rents are fully dissipated at the margin so that the expected lifetime earnings of the twin brothers are identical. 
While the means of lifetime earnings streams are identical, the nature of the respective employment situations as constructed guarantees that the standard deviations of year-to-year earnings would be significantly different.

In the case of the wrongful death of the twins, the forensic economist ignoring the effects of income variance would give an identical present value for these two lifetime earning streams. To a financial analyst utilizing a capital asset pricing model and following the principle that only "certain" cash flows are to be valued at risk-free discount rates, the streams would be given different current values reflecting the differing variances of the income streams. A risk adjustment would be suggested that increased the discount rate (a premium would be added) and thus lowered the present value of lifetime earnings for the free-lance financial advisor, brother A.

Differences in the discount rate applied to the twin brothers' future income will then result in differences in the present value of lifetime earnings under this scenario, even when all other dimensions are identical as per construction. Margulis, Biederman and Baesemann, and Bell and Taub are claiming that well-known principles of finance require that the risky income stream be discounted at a non risk-free rate and accordingly, that a lower present value lump sum award be given. Professor Ireland responds that even if using riskfree rates is questionable from a purely computational standpoint, it is nonetheless required by the Supreme Court (in Pfeifer). Unless some method can be found by which the uncertainty of income variation can be collapsed into an adjustment of the level or length of assumed income, then the two income streams with identical median earnings level are to be valued identically by Professor Ireland.

A table showing hypothetical income streams was suggested by a referee and might clarify the issue. Consider the two brothers, $\mathrm{A}$ and $\mathrm{B}$ and let the values reflect the probability distributions of their earnings. The standard approach interprets "expected value" as a certainty equivalent stream and discounts accordingly. Yet brother A's likely income stream surely would have exhibited greater uncertainty (here defined as variance year-to-year) than brother B's steady university wages. The crux of contention can be stated as a question: Should the two lost income present values be identically calculated? Professor Ireland would seem to answer in the affirmative and Professors Bell and Taub in the negative. If these two brothers projected incomes were instead the projected returns to two companies facing differing competitive conditions, then would the market for equities place a lower value on Company $\mathrm{A}$ in recognition of the risk, however precisely defined?

Table 1

\begin{tabular}{|c|c|c|c|c|c|c|}
\hline Individual & $\begin{array}{c}\text { Income in } \\
\text { year 1 }\end{array}$ & Probability & $\begin{array}{c}\text { Income in } \\
\text { year 2 }\end{array}$ & Probability & $\begin{array}{c}\text { Income in } \\
\text { year 3 }\end{array}$ & Probability \\
\hline A & $\$ 60$ & .2 & $\$ 80$ & .2 & $\$ 60$ & .2 \\
& $\$ 100$ & .6 & $\$ 100$ & .6 & $\$ 100$ & .6 \\
& $\$ 140$ & .2 & $\$ 120$ & .2 & $\$ 140$ & .2 \\
\hline B & $\$ 100$ & 1.0 & $\$ 100$ & 1.0 & $\$ 100$ & 1.0 \\
\hline
\end{tabular}




\section{Related and Unresolved Issues}

Investment Returns or Discount Rate Only

The issue of discount rates is clouded by the distinction between interpreting the discount rate as a reduction of future losses to present value or as a projection of earnings on the awarded lump sum. It has been understood, at least at the Circuit Court of Appeals level, that the discount rate can be understood as an earning rate on the invested lump sum. In Shin-Tao v. McDonnell Douglas Corp., the Court held that "post-judgment losses ... are to be discounted to present value in order to offset future earning power of a present lump sum award for future losses" (at p. 52.) While this addressed only postjudgment losses, the logic is clearly applicable to all discounted present value sums. If this conceptualization of a present value damages calculation is appropriate, it supports the consideration of non-risk free discount rates. An alternative viewpoint holds that we should view the present value calculation as independent from any investment plans for the awarded lump sum. This perspective tends to minimize concerns over risk-adjusted discount rates and recommends reliance upon a risk-free rate.

\section{Best and Safest}

The discussion may be thought to turn on the definition of "best and safest" investments, a phrase from Chesapeake, cited as authority in Pfeifer. A "best" investment would mean something very different from a "safest" investment thus the language of the legally controlling precedent sets up confusion by failing to appreciate the unavoidable tradeoff between best and safest investments. As noted above, depending on one's interpretation, the terminology upon which the legal principle is based is subject to multiple interpretations and can be viewed as being either contradictory or redundant.

\section{Arguments for Ignoring Income or Productivity Variance}

There are some standard efficiency arguments for ignoring income variance-risk adjustments in the selection of a discount rate, even if the theoretical case for its consideration is granted. First, consider the parallels with the efficiency argument for punitive damages. If some accidents or tortfeasors are undetected or if some elements of economic damages are systematically excluded from consideration in the litigation process, then a degree of "overcompensation" may be seen as a partial correction, "second-best" arguments aside. Two large categories of potential damage under-assessment exist in the present system of tort law. Regarding undetected injuries, although the common law doctrine that the "action dies with the man" is no longer controlling, it is still true that US law of wrongful death, like most civil law, relies on self-enforcement by the aggrieved parties. Thus losses are claimed by and awarded to, survivors (Wisconsin is a "loss-to-survivors" state) or an estate (the alternative is "loss- 
to-estate"). This means that the gravel truck company that negligently kills twin brother B, father of five, will face lifetime earning damages payable to the survivors or the surviving estate while the gravel truck company that negligently kills brother A, a bachelor with no dependent relatives, will face only the possibility of criminal charges and no civil liability.

Secondly, even if there are survivors to press claims of lost support and inheritance, it is well known (Posner, 1998, p.215) that the economic value of life of a decedent, to the decedent, is omitted from the calculation of pecuniary wrongful death damages. There is thus a partial misstatement of such damages in wrongful death litigation in most jurisdictions when viewed from the standpoint of social value. Considering the likely imprecision involved in the assessment of damages under current practice from this and other theoretical considerations of social utility, the urgency of attempts to fine tune the discount rate by adjusting for risk variance is undermined.

Investment Returns vs. Lifetime Earnings:

Is the Finance Principle Applicable?

Despite the counter arguments, it is this writer's opinion that the likely variance in income streams being projected is an item bearing on the selection of a proper discount rate and is appropriate for further analysis by forensic economists. Is it fair to value a lifetime of income stream payments for labor services the same way an investor would value a similar stream of payments emanating from a financial or business asset? In one sense no, since there is no comparable market for a person's lifetime earnings in any manner equivalent or similar to the market for financial or business assets. Yet the same conversion of a flow of likely income into a stock of present value lump sum wealth is necessitated by the common law of tort damages. The absence of a ready "explicit" valuation of lifetime earnings makes such calculations more problematic in comparison say, to a business or commercial property valuation. But this issue is present whether or not the separate issue of a potential for risk premiums for income variance is confronted.

While there may seem to be no parallel between the fluctuating returns of equity investments and the steady raises enjoyed, for example by government or union contract workers, there is similarly no comparability between the earnings of a commission-only municipal bond salesman with highly variable earnings and the predictably reliable bond interest payments of a U.S. Treasury bond. Perhaps a tailoring of likely earnings variability and investment instrument is feasible. Given sufficient longitudinal income data, perhaps a "beta" of income variability could be developed patterned after the "beta" of investment return volatility. It would seem reasonable to introduce a higher discount rate reflecting equity yields in the case of the commission-only municipal bond seller whose income is seen to fluctuate. In the case of a secure government worker with a history of steady raises on the other hand, a calculation of present value based on risk-free returns might be given more weight. 


\section{Conclusion}

The entire discussion above could be rendered moot if the end result of considering risk-adjusted discount rates does not result in substantial differences in present value calculations in comparison to using risk-free discount rates. However, the results of introducing risk-adjusted discount rates will usually be material. Consider again the commission-only municipal bond seller with an historic income fluctuating between $\$ 300,000$ and $\$ 800,000$ annually. Drawing parallels is not perfect but average returns to small company stocks certainly provide a starting point. The variability of commissions to a salesperson easily compares to the volatility of earnings of a small company. The latest Ibbotson and Associates yearbook puts long-term average nominal yields at $12.5 \%$ for small company stocks and $11.0 \%$ for large company stocks. In comparison to average nominal risk-free U.S. Treasury Bond yields on the order of $5 \%$, present value differences can be substantial over long time periods. It is difficult to imagine that the Supreme Court's desire to see good science in the courtroom as revealed by its Daubert decision would allow it to exclude a forensic economist's calculation that reflected risk-adjusted discount rates where such rates were supported by a consensus of the relevant scientific community.

On the other hand, in the concluding section of Pfeifer, the Supreme Court majority writes that they are not suggesting that the trial judge "should embark on a search for "delusive exactness" (p. 552, apparently a Holmesian phrase). In stating this, they may be implicitly acknowledging the well-known economic principle that, given a positive marginal cost of greater precision, some imprecision may be optimal. While this is indisputable as a general principle, it is up to forensic economists to consider further fine-tuning of the discount rate such as is being tentatively considered here.

Judge Richard Posner has written in economic terms about the Supreme Court's law-making. He compares a Supreme Court precedent to productive social capital, having a supply function (quantity supplied is modeled as a function of the degree of social conflict or uncertainty) and exhibiting depreciation over time. He points out that Supreme Court law is and should be the most general and durable of all law and that when Supreme Court law becomes specific, it sacrifices its durability and longevity (Posner, p. 587-96). Perhaps in Pfeifer, by clearly and specifically declaring that "below-market" "risk-free" discount rates of between " $1 \%$ and $3 \%$ " are to be employed by forensic economists, the Supreme Court has pursued a "delusive exactness." Following Posner's analysis of Supreme Court decisions as legal "capital," we may however conclude that Pfeifer's instructions for present value are overly specific and will quickly depreciate in the face of legal challenges, academic discussions, and in light of the varied and constantly evolving practice of forensic economists. Bell and Taub's and Ireland's contributions and the present comment have all hopefully made a substantial contribution to this continuing dialogue over the proper measurement of tort damages, which is our shared goal. 


\section{References}

Albrecht, Gary R., "Compensatory Damages and the Appropriate Discount Rate: A Comment," Journal of Forensic Economics, 1992, 6(3), 271-272.

and John C. Moorhouse, "On the Derivation and Consistent Use of Growth and Discount Rates for Future Earnings," Journal of Forensic Economics, 1989, 3(2), 95101.

Bell, Edward B. and Allan J. Taub, "Dedicated Portfolios and the Present Value of Lost Earnings," Journal of Forensic Economics, 1990, 4(1), 1-6. and , "Some Issues Concerning Risk Adjustments in Damage Calculations," Litigation Economics Digest, 1999, 4(2), 153-155.

Biederman, Daniel K., and Robert C. Baesemann, "Risk-Free vs. Risk-Adjusted Discount Rates: A Comment," Journal of Forensic Economics, 1996, 9(1), 45-47.

Bonham Carl, and Sumner J. La Croix, "Forecasting Earnings Growth and Discount Rates: New Evidence from Time Series Analysis," Journal of Forensic Economics, 1992, 5(3), 221-231.

Ewing, Bradley T., James E. Payne, and Michael J. Piette, "The Time Series Behavior of the Medical Cost Net Discount Rate: Implications for Total Offset and Forecasting," Journal of Forensic Economics, 2001, 14(1), 53-61.

Haslag, J. H., M. Nieswiadomy and D. J. Slottje, "Are Net Discount Rates Stationary? The Implications for Present Value Calculations: Comment," Journal of Risk and Insurance, 1994, 61(3), 503-512.

Havrilesky, Thomas, "New Evidence on Expected Long Term Real Interest Rates," Journal of Forensic Economics, 1988, 1(2), 19-23.

Haydon, Randall B., and Samuel C. Webb, "Selecting the Time Period over Which the Net Discount Rate is Determined for Economic Loss Analysis," Journal of Forensic Economics, 1992, 5(2), 137-147.

Horvath, Philip A., and Edward L. Sattler, "Calculating Net Discount Rates-It's Time to Recognize Structural Changes: A Comment and Extension," Journal of Forensic Economics, 1997, 10(3), 327-332.

Ireland, Thomas R., "Forensic Implications of Inflation Adjusted Bonds," Litigation Economics Digest, 1997, 2(2), 92-102.

"Response to Bell and Taub, 'Some Issues Concerning Risk Adjustments in Damages Calculations," Litigation Economics Digest, 1999, 4(2), 157-158.

Margulis, Marc S., "Compensatory Damages and the Appropriate Discount Rate," Journal of Forensic Economics, 1992, 6(1), 33-41.

Nowak, Laura S., "Empirical Evidence on the Relationship between Earnings Growth and Interest Rates," Journal of Forensic Economics, 1991, 4(2), 187-202.

Peláez, Rolando F., "The Below-Market Method: A Rejoinder to Professor Gilbert," Journal of Forensic Economics, 1997, 10(1), 77-90.

Posner, Richard A., Economic Analysis of Law, $5^{\text {th }}$ ed., New York: Aspen Publishers, 1998.

, Frontiers of Legal Theory, Cambridge, MA: Harvard Univ. Press, 2001.

Chesapeake \& Ohio Railway Co. v. Kelley, 241 US 485 (1983)

Daubert v. Merrell Dow Pharmaceuticals, 509 US 579 (1993)

General Electric Co. v. Joiner, 522 US 136 (1997)

Jones \& Laughlin Steel Co. v. Pfeifer, 462 US 523 (1983)

Kumho Tire Co. v. Carmichael 526 US 137 (1999)

Norfolk \& Western R. Co. v. Liepelt, 444 US 490 (1980)

Shu-Tao Lin v. McDonnell Douglas Corp., 742 F. 2 d 45 (2d Cir. 1984) 